\title{
Effects of Work Motivation and Leadership toward Work Satisfaction and Employee Performance: Evidence from Indonesia
}

\author{
Irwan PANCASILA ${ }^{1}$, Siswoyo HARYONO ${ }^{2}$, Beni Agus SULISTYO ${ }^{3}$
}

Received: March 17, 2020 Revised: March 28, 2020 Accepted: May 01, 2020

\begin{abstract}
The purpose of this study is to determine the effect of work motivation and leadership on job satisfaction and its implications on employee performance. A total of 355 samples of Bukit Asam Coal Mining Company Ltd. in Indonesia were selected proportionally with random sampling. Data were obtained through questionnaires. Data analysis technique employed structural equation modeling (SEM) with AMOS 22. The results of the study show that leadership and work motivation have a positive and significant effect on job satisfaction. Leadership has a more considerable influence (0.263) than work motivation (0.171) toward employee job satisfaction. The influence of leadership towards job performance is 0.175 . The influence of work motivation towards job performance is 0.166 . Job satisfaction has the most dominant influence (0.363) towards employee performance. The direct effect of leadership on employee performance is 0.175 greater than the indirect influence of leadership on employee performance through employee job satisfaction, which is only 0.096. Likewise, the direct effect of work motivation towards employee performance is 0.166 greater than the indirect effect of work motivation towards employee performance through employee job satisfaction, which is only 0.062 . Thus, job satisfaction does not mediate the effects of leadership and work motivation toward employee performance.
\end{abstract}

Keywords : Leadership, Work Motivation, Satisfaction, Performance, Indonesia.

JEL Classification Code: D20, D22, D23

\section{Introduction}

Companies in the industry 4.0 and ree market era are currently facing more severe challenges than previous eras. The challenge for each company is to prepare themselves to face globalization in order to remain maximally profitable while reducing losses from the global competition through effective and efficient management of resources. Companies must have competitive advantages through resource wealth that is not only tangible and intangible but also unique

${ }^{1}$ First Author. Universitas Tridinanti Palembang, Indonesia ${ }^{2}$ Corresponding Author. Professor and Head, Doctoral Management Program, Postgraduate Studies, Universitas Muhammadiyah Yogyakarta, Indonesia [Postal Address: Jl. Brawijaya, Tamantirto, Kec. Kasihan, Bantul, Yogyakarta, 55183, Indonesia]

Email: profsis12@gmail.com

${ }^{3}$ Universitas Muhammadiyah Yogyakarta, Indonesia

(c) Copyright: The Author(s)

This is an Open Access article distributed under the terms of the Creative Commons Attribution Non-Commercial License (http://Creativecommons.org/licenses/by-nc/4.0/) which permits unrestricted noncommercial use, distribution, and reproduction in any medium, provided the original work is properly cited.
(Fo, 2015). Of the many resources, the most valuable resource is human resources. Without adequate human resources, other resources will be idle. Awosusi and Fasanmi (2014) stated that the human factor is the most vital and critical of all organizational resources.

Directorate of Mineral, Mining, and Geothermal Business, Directorate of Mineral (2010) argued Indonesia is one of the largest coal exporting countries in the world, and in 2020 it is predicted that exports will reach 361 million tons. Coal production 15 years ago was only 31 million tons, currently increasing to eight times and in 2010 to 256 million tons. Indonesia, which previously was an oil exporter country, has now become an oil importer, so coal is increasingly essential to replace oil in the composition of energy use in Indonesia. Table 1 is a prediction of Total Production, Domestic Needs, and Exports in the year of 2015 to 2025.

The domestic and international coal market conditions have been very enthusiastic with a high price level. Currently, there are many companies engaged in coal exploration, so that the level of competition that must be faced by PT Bukit Asam becomes increasingly more oppressive. The foremost 
Table 1: The Prediction of Total Production, Domestic Needs and Exports 2015 to 2025

\begin{tabular}{|l|c|c|c|}
\hline \multicolumn{1}{|c|}{ Needs } & $\mathbf{2 0 1 5}$ (Tons) & $\mathbf{2 0 2 0}$ (Tons) & $\mathbf{2 0 2 5}$ (Tons) \\
\hline Production & 321.000 & 361.000 & 405.000 \\
\hline Domestic & 120.000 & 170.000 & 220.000 \\
\hline Export & 201.000 & 191.000 & 185.000 \\
\hline
\end{tabular}

Source: Directorate of Mineral (2010)

challenge is intense competition with private companies mines both domestic and international as well as maintain export markets.

If the employee's performance is excellent, likely, the company's performance is also good. A person's performance will be excellent if he has high skills, is willing to work because he is paid, and has a better future expectation. Aamodt (2012) stated that giving motivation to the organization aims to encourage the working spirit of employees to be willing to work hard by giving all their abilities. If the employee feels motivated, then he will get satisfaction in the work, and he works more enthusiastically, which will ultimately improve his performance. Some empirical studies provide inconsistent results, including those carried out by Alnıaçı, Alnıaçık, Akçin, and Erat (2012), who revealed that career motivation has a positive correlation toward job satisfaction and organizational commitment. Arasli et al. (2014) depicted that there is a significant positive correlation between intrinsic motivation and job satisfaction. The research of Anghelache (2015) shows the lack of correlation between motivation and job satisfaction.

In addition to work motivation factors, according to Gordon and Yukl (2004) leadership factors are also factors that also influence job satisfaction and employee performance For over a half-century, leadership researchers have attempted to identify the aspects of leadership that improve organizational performance, yet the answer is still elusive. Leadership is an essential factor in providing direction to employees. Leadership is significant at all levels within the company. Effective leadership helps to develop teamwork and the integration of individual and group goals (Oluseyi \& Hammed, 2009). Previous research relevant to the influence of leadership on job satisfaction was carried out by Munir, Rahman, Malik, and Ma'amor (2012), who revealed that transformational leadership and employee job satisfaction were a positive, linear and robust relationship ( $\mathrm{r}=0.75)$. Cakmak, Öztekin, and Karadağ (2015) showed that leadership has a mediumlevel positive effect on job satisfaction. Aderamo and Salau (2013) have research on leadership and show the results are inconsistent, that transformational leadership has a positive impact on job satisfaction, and transactional leadership has a negative impact on job satisfaction.
Bukit Asam Performance Coal Mining Company Ltd.'s performance at this time is still low due to a decrease in net income and sales from previous years. The low performance of the company is inseparable from the low performance of employees. Al-Khalifa and Peterson (2004) say that employee performance will increase if employees feel satisfied in their work and are motivated to do work. Mehta, Dubinsky, and Anderson (2003) provides an overview of the causality between leadership, motivation, and employee performance. Low performance of employees of Bukit Asam Coal Mining Company Ltd. allegedly as a result of low employee motivation and employee dissatisfaction with what was received. There are still some employees who are absent during working hours, high absenteeism, and less entworking lazily is a factor that causes their tasks and responsibilities cannot be completed on time so that employee performance decreases. This empirical phenomenon is also relevant to research by Arshadi (2010) that revealed three psychological needs of work motivation and job performance. Hayati and Caniago (2012) showed the relationship between work motivation and job performance. Imam, Armanu, Umar, and Djumahir (2015) revealed that there are three variables significantly affecting job performance; those variables are leadership style, corporate culture, and employee motivation. Azin and Reihane (2013) show the result that job motivation correlated with job performance.

Dissatisfaction at work is also the result of the function and position of employees in the organization. Employees who have a higher position would fill satisfied because they have more autonomy than regular employees. Their work more varied and have more freedom to do their assessment. Employees with low positions are more likely to experience dissatisfaction and boredom because their work is less challenging, and their responsibilities are small. Employees who are highly educated but have low positions get jobs that are not commensurate with their abilities and expertise. With many employees of Bukit Asam Coal Mining Company Ltd., those who feel dissatisfied will result in a lack of overall employee performance. Oluseyi and Hammed (2009) illustrate the existence of a strong relationship between leadership, work motivation, time, and performance management.

Leadership effectiveness was the most potent contributor to employees' performance, followed by work motivation, but time management was the least contributor to employees' performance in the workplace. Lo, Ngui, and Ayob (2011) provide an overview of leadership and job satisfaction. Effective leadership and employee job satisfaction are two fundamental factors for organizational success in achieving its goals and objectives. Although, in general, work motivation affects job satisfaction, there are still contradictions, such as research conducted by Anghelache (2015) showed the lack of correlation between motivation 
and job satisfaction. Kelidbari, Fadaei, and Ebrahimi (2016) gave a result that the role of ethical leadership in the performance of employees is indirectly significant. (Awosusi \& Fasanmi, 2014) showed leadership effects on employee performance of hotels, either directly and indirectly, through innovation and differentiation, an intervening variable. Skeepers and Mbohwa (2015) revealed that leadership visibility and behavior affect the safety industry and safety performance in the construction industry. Kalkavan and Katrinli (2014) identified between satisfaction and work performance. Farooqui and Nagendra (2014) showed a positive relationship between job satisfaction and job performance.

Based on the description above, it is clear that job satisfaction and employee performance are low at Bukit Asam Coal Mining Company Ltd. caused by less effective leadership that is less empowering employees so that their work motivation is lacking. Less effective leadership on Bukit Asam Coal Mining Company Ltd causes leadership that gives less attention to its employees to develop, less able to motivate employee work, and lack of leadership competence in managing existing resources, causing employees to be reluctant to give criticism and suggestions to their leaders. Job satisfaction will be o fulfilled if motivation and leadership go well. Employee performance at Bukit Asam Coal Mining Company Ltd needs to be considered by management because the performance is directly related to the results to be achieved by the company. Work motivation and leadership at Bukit Asam Coal Mining Company Ltd are essential factors in achieving performance.

By having employees who are highly motivated and supported by effective leadership, they will encourage employees at Bukit Asam Coal Mining Company Ltd. to work and solve the problem according to the rules. Another advantage is that employees can innovate in completing their tasks so that they will lead to a feeling of satisfaction in work, and ultimately improve the performance of individuals and companies. This study will examine the effect of work motivation and leadership toward job satisfaction and its implications on the performance of employees of Bukit Asam Coal Mining Company Ltd., Tanjung Enim, Sumatera Selatan, Indonesia.

\section{Literature Review and Hypothesis Development}

\subsection{The Relationship between Work Motivation and Job Satisfaction}

One crucial factor that causes humans to work is because they want to fulfill their needs. A company needs to pay attention to what its employees' needs and expectations are, what talents and skills they have and how they plan to work in the future. If the company can find out these things, it will be easy to put the employee in the right position to have productive employees (Newstrom, 2014). The presence of is given if the target will make employees feel the satisfaction in working, employees who feel satisfied will work optimally towards their duties and responsibilities, which will ultimately improve employee performance.

Based on several theories that underlie employee motivation, according to Aamodt (2012), such as the Needs Theory, Achievement Theory, Two-Factor Theory, Justice Theory and Expectation Theory which argue that an employee will feel satisfied if they. These needs are the dimensions of work motivation in order to improve job satisfaction. The results of several previous studies have varied results, but in general work, motivation has a positive and significant effect on employee performance. Research conducted by Alnıaçik et al. (2012), the career motivation has a positive correlation toward job satisfaction and organizational commitment. Research that was done by Arasl1, Daşkın, and Saydam (2014) depicted that there is ta significant positive correlation between intrinsic motivation and job satisfaction. The research of Anghelache (2015) shows the lack of correlation between motivation and job satisfaction.

H1: Work motivation has a positive and significant effect on job satisfaction.

\subsection{The Relationship between Leadership and Job Satisfaction}

Leadership is an essential factor in providing direction to employees. Leadership that can foster employee motivation is leadership that can foster the self-confidence of employees in carrying out their respective duties. In situational leadership theory by Harsey et al. (2012), a leader effective one must be flexible enough to adjust differences between employees and situations because employee performance depends on whether or not leadership is compatible with situational leadership factors. Kinicki and Fugate (2015), Wikaningrum, Udin, and Yuniawan (2018) suggest that job satisfaction is closely related to the attitude of employees towards their work, work situation, a collaboration between leaders and fellow employees. In leading an organization, a leader can create the satisfaction of an employee for his leadership. Therefore the selection of leadership style that is rightly applied to subordinates will have an impact on employee job satisfaction.

There is some research on the influence of leadership on employee job satisfaction. The results of the study varied but generally concluded that leadership had a positive and significant influence on employee job satisfaction. The research of Munir et al. (2012) revealed that 
transformational leadership and employee job satisfaction sare indicated a positive, linear, and robust relationship $(r=0.75)$. Furthermore, the research of Cakmak et al. (2015) shows that ethical leadership constructively has significant predictive ability regarding job satisfaction. Research by Aderamo and Salau (2013) on leadership shows the results that transformational leadership has a positive impact on job satisfaction, and in reverse, transformational leadership hurts job satisfaction. The last research that was done by Walumbwa, Bani, Peng, and John (2005) revealed that transformational leadership has a strong and positive effect on organizational commitment and job satisfaction in both cultures.

H2: Leadership has a positive and significant effect on job satisfaction

\subsection{The Relationship between Work Motivation and Performance}

Motivation is a process of the need to satisfy, which means that when specific factors meet a person's needs, people will exert every effort towards achieving the goals of the organization with maximum work results. Newstrom (2014) states that if better performance can increase employee benefits in a fair and balanced manner, then job satisfaction will increase; in other cases, employee satisfaction is the feedback that affects self-image and motivation to improve performance. Gibson, Ivancevich, and Konopaske (2011) state that motivation is as an attitude of leaders and employees towards work situations in the organizational environment. Those who are positive (pro) towards their work situation will show high work motivation and vice versa if they behave negatively (counter) to their work situation will show low work motivation. Employees who have high work motivation tend to give excellent performance.

Grote and Grote (2011), Gomez-Mejia, Balkin, and Cardy (2012) argued that increasing employee motivation would lead to an increase in the performance of individuals, groups, and organizations. Research by Arshadi (2010) gave results that three psychological needs predicted work motivation and job performance. Hayati and Caniago (2012) showed the relationship between work motivation and job performance. Imam et al. (2015) revealed that there are three variables significantly affecting job performance; those variables are leadership style, corporate culture, and employee motivation. Azin and Reihane (2013) show that job motivation correlated with job performance.

H3: Work motivation has a positive and significant effect on employee performance.

\subsection{The Relationship between Leadership and Job Performance}

According to Yukl (2010), an effective leader must be able to differentiate between employees and the work environment because employee performance depends on whether or not the leadership style is suitable for environmental, situational factors. Effective leadership is leadership that can direct subordinates to perform their duties well, motivate and move subordinates, and have better competencies so that employee performance will increase. Oluseyi and Hammed (2009) state that leadership is critical at every level of the organization; effective leadership moves individuals and groups to achieve organizational goals.

Ivancevich and Konopaske (2012), Juan, Clare, Steve, and Alan (2012) stated that leaders are people who can provide work motives to subordinates in such a way that they want to work sincerely in order to achieve organizational goals effectively and efficiently. According to Juan et al. (2012), effective leadership is the most reliable support in improving employee performance.

Research by Kelidbari et al. (2016) gave the result that the role of ethical leadership in the performance of employees is indirectly significant. (Semuel, Siagian, \& Octavia, 2017) showed leadership effects on employee performance of hotels, either directly and indirectly, through innovation and differentiations intervening variables. Skeepers and Mbohwa (2015) revealed that leadership visibility and behavior affects the industry's safety culture and safety performance in the construction.

H4: Leadership has a positive and significant effect on employee performance

\subsection{The Relationship between Job Satisfaction and Job Performance}

A critical target in Human Resource Management in an organization is the creation of job satisfaction for members of the organization concerned (Cho, 2020). Job satisfaction would have a good effect on organizational performance. Dessler and Varrkey (2005) suggest that employees who get job satisfaction have better attendance and regulation records, and have better job performance than employees who do not get job satisfaction. Job satisfaction has an essential meaning for both employees and companies. The fundamental factors that are closely related to performance are job satisfaction. Employee job satisfaction can e realized if motivational factors such as service rewards, security, interpersonal influence, work environment conditions, and opportunities for self-development and improvement. From 
the description, performance is influenced by motivation and job satisfaction (Colquitt, Lepine, Wesson, \& Gellatly, 2011).

Research by Kalkavan and Katrinli (2014) identified the effect between satisfaction and work performance. Farooqui and Nagendra (2014) showed a positive relationship between job satisfaction and job performance. Based on this, there is a positive influence on employee job satisfaction on employee performance. In other words, the more employees feel satisfaction in working; then they will create better morale and results that will ultimately increase their performance.

H5: Job satisfaction has a positive and significant effect on employee performance.

\section{Research Methods}

This research uses quantitative design. Variable research consists of leadership, work motivation, job satisfaction, and employee performance measured by developing instruments with a 1 - 5 Likert scale. The scale represents the ranking from 'strongly disagree' to 'strongly agree.' The leadership variable is the leadership practice applied by structural leaders or supervisors and is measured based on the opinions of respondents regarding perceptions about the implementation of their supervisor's leadership behavior. While work motivation, job satisfaction, and employee performance are measured based on employee perceptions of their own experiences and experiences or self-assessment. The population in this study are all permanent employees of 3,075 people in Bukit Asam Coal Mining Company Ltd. From 3,075 people, only 355 respondents were selected proportionally by random sampling method. According to Hair, Black, Babin, and Anderson (2013), the number of respondents is at list five to ten times the number of indicators of the constructs in the developed full model SEM. Data collected through the distribution of instruments and face to face by researchers.

The survey utilizes instruments for 355 respondents. The questioner is filled in and returned completed by the respondent. The method used in this study is the Second Order Structural Equation Modeling (SEM) with AMOS version 22.0 software to analyze data and answer hypotheses. The indicator testing of each variable by the goodness of fit (GOF) technique.

With this technique, the measurement will apply convergent validity to test the validity of the indicators developed. This study used the maximum likelihood estimation (MLE) technique is used in this study. The result of the multivariate critical ratio (c.r) is 1.694 . Assessment of each questionnaire item using a confirmatory factor analysis (CFA) method to test the construct relationship with indicators based on the theory developed. Construct reliability test used variance extracted (AVE). Table 2 is the result of the CFA test, which shows the loading of the questionnaire questions $\geq 0.5$; all indicators are valid (Sekaran \& Bougie, 2013).

Table 3 shows construct reliability $(\mathrm{CR}) \geq 0.7$ and variance extracted (AVE) is $\geq 0.5$ in each construct, so it can be concluded that all constructs are reliable. The CFA test results, $\mathrm{CR}$, and VE in Table 3 concluded that all indicators could used to measure variables and analyze research data.

\section{Results and Discussion}

\subsection{SEM Results}

The hypothesis testing in this study using the SEM model uses AMOS 22.0 software. Figure 1 shows the goodness of fit test (GOF) results of full model SEM. The results of the goodness of fit (GOF) test are as follows: Chi-Square = 537,762 , probability $=0.398, \mathrm{df}=530, \mathrm{CMIN} / \mathrm{DF}=1.015$, $\mathrm{GFI}=0.922, \mathrm{AGFI}=0.907, \mathrm{CFI}=0.999, \mathrm{NFI}=0.950, \mathrm{IFI}$ $=0.999, \mathrm{RMSEA}=0.006$ and $\mathrm{RMR}=0.017$. The results of the GOF criteria have met the required cut-off value, so the research model has been fit and can be used to analyze and test the proposed hypothesis (see Table 4).

\subsection{The Relationship between Work Motivation and Job Satisfaction}

Based on Table 4, Relationship between work motivation and job satisfaction has a value of $2.874(>1.96)$ o Hypothesis $1 \mathrm{~s}$ accepted. Thus work motivation has a positive and significant effect on job satisfaction. One of the essential factors that cause humans to work is because they want to fulfill their needs. If the company meets the needs and expectations of its employees, what talents and skills they have, and the opportunity to progress and develop, then employees will feel satisfied in their work. If the employee feels satisfied, then by themselves, they will work optimally so that their performance will increase. The needs expected by employees are the dimensions of work motivation in order to improve job satisfaction. Some studies have given varied results, but in general work, motivation has a positive and significant effect on employee job satisfaction. The results of this study are in line with the findings of Alnıaçık et al. (2012), which state that career motivation has a positive correlation toward job satisfaction and organizational commitment. This research also supports Arasli et al. (2014), who depicted that there is a significant positive correlation between intrinsic motivation and job satisfaction. A slightly different result is Anghelache (2015) shows the lack of correlation between motivation and job satisfaction. 
Table 2: Validity Test Result Based on Fit Model's Loading Factors

\begin{tabular}{|c|c|c|c|c|}
\hline Constructs \& Dimensions & Loading Factor $(\lambda \geq 0.5)$ & Indicators & Loading Factor $(\lambda \geq 0.5)$ & Conclusion \\
\hline \multicolumn{5}{|l|}{ Work Motivation (WM) } \\
\hline \multirow{2}{*}{$\operatorname{Basic}\left(\mathrm{X}_{1.1}\right)$} & \multirow{2}{*}{0.982} & $\mathrm{WM}_{01}$ & 0.880 & Valid \\
\hline & & $\mathrm{WM}_{02}$ & 0.887 & Valid \\
\hline \multirow{2}{*}{ Safety $\left(\mathrm{X}_{1.2}\right)$} & \multirow[t]{2}{*}{0.992} & $\mathrm{WM}_{03}$ & 0.880 & Valid \\
\hline & & $\mathrm{WM}_{04}$ & 0.900 & Valid \\
\hline \multirow{2}{*}{ Social $\left(X_{1.3}\right)$} & \multirow{2}{*}{0.990} & $\mathrm{WM}_{06}$ & 0.831 & Valid \\
\hline & & $W_{08}$ & 0.850 & Valid \\
\hline \multirow{2}{*}{ Esteem $\left(\mathrm{X}_{1.4}\right)$} & \multirow{2}{*}{0.922} & $W_{09}$ & 0.833 & Valid \\
\hline & & $W_{11}$ & 0.881 & Valid \\
\hline \multirow{2}{*}{ Self-Actualization $\left(\mathrm{X}_{1.5}\right)$} & \multirow{2}{*}{0.929} & $\mathrm{WM}_{14}$ & 0.879 & Valid \\
\hline & & $\mathrm{WM}_{15}$ & 0.893 & Valid \\
\hline \multicolumn{5}{|l|}{ Leadership (LD) } \\
\hline \multirow{4}{*}{ Making a decision $\left(\mathrm{X}_{2.2}\right)$} & \multirow{4}{*}{0.989} & $\mathrm{LD}_{05}$ & 0.752 & Valid \\
\hline & & $\mathrm{LD}_{06}$ & 0.858 & Valid \\
\hline & & $\mathrm{LD}_{07}$ & 0.824 & Valid \\
\hline & & $\mathrm{LD}_{08}$ & 0.838 & Valid \\
\hline \multirow{2}{*}{$\begin{array}{l}\text { Giving and seeking } \\
\text { Information }\left(\mathrm{X}_{2.3}\right)\end{array}$} & \multirow{2}{*}{0.986} & $\mathrm{LD}_{09}$ & 0.836 & Valid \\
\hline & & $\mathrm{LD}_{10}$ & 0.710 & Valid \\
\hline \multirow{2}{*}{ Building Relationship $\left(\mathrm{X}_{2.4}\right)$} & \multirow{2}{*}{0.973} & $\mathrm{LD}_{13}$ & 0.746 & Valid \\
\hline & & $\mathrm{LD}_{14}$ & 0.717 & Valid \\
\hline \multicolumn{5}{|l|}{ Job Satisfaction (JS): } \\
\hline \multirow{3}{*}{ Compensation $\left(\mathrm{Y}_{1.1}\right)$} & \multirow{3}{*}{0.926} & $\mathrm{JS}_{01}$ & 0.799 & Valid \\
\hline & & $\mathrm{JS}_{03}$ & 0.863 & Valid \\
\hline & & $\mathrm{JS}_{06}$ & 0.820 & Valid \\
\hline \multirow{2}{*}{ Working Condition $\left(\mathrm{Y}_{1.2}\right)$} & \multirow{2}{*}{0.990} & $\mathrm{JS}_{07}$ & 0.745 & Valid \\
\hline & & $\mathrm{JS}_{09}$ & 0.747 & Valid \\
\hline Company Policy $\left(\mathrm{Y}_{1.3}\right)$ & 0.989 & $\mathrm{JS}_{12}$ & 0.840 & Valid \\
\hline \multirow{2}{*}{ Opportunity to develop $\left(\mathrm{Y}_{1.4}\right)$} & \multirow{2}{*}{0.988} & $\mathrm{JS}_{13}$ & 0.861 & Valid \\
\hline & & $\mathrm{JS}_{14}$ & 0.847 & Valid \\
\hline \multicolumn{5}{|l|}{ Job Performance (PE): } \\
\hline The quantity of work $\left(\mathrm{Y}_{2.1}\right)$ & 0.986 & $\mathrm{JP}_{01}$ & 0.829 & Valid \\
\hline Quality of work $\left(\mathrm{Y}_{2.2}\right)$ & 0.987 & $\mathrm{JP}_{03}$ & 0.871 & Valid \\
\hline \multirow{2}{*}{ Job Knowledge $\left(Y_{2.3}\right)$} & 0900 & $\mathrm{JP}_{05}$ & 0.886 & Valid \\
\hline & & $\mathrm{JP}_{06}$ & 0.892 & Valid \\
\hline Creativity $(Y)$ & 0902 & $\mathrm{JP}_{07}$ & 0.824 & Valid \\
\hline Creativity $\left(Y_{2.4}\right)$ & 0.902 & $\mathrm{JP}_{08}$ & 0.837 & Valid \\
\hline Inisiative $(Y)$ & 0875 & $\mathrm{JP}_{13}$ & 0.881 & Valid \\
\hline mistative $\left(\mathrm{r}_{2.7}\right)$ & & $\mathrm{JP}_{14}$ & 0.868 & Valid \\
\hline
\end{tabular}


Table 3: Reliability Test Result Based on Fit Model

\begin{tabular}{|l|c|c|c|}
\hline \multicolumn{1}{|c|}{ Variables } & $\begin{array}{c}\text { Construct } \\
\text { Reliability of } \mathbf{\geq 0 . 7}\end{array}$ & $\begin{array}{c}\text { Variance } \\
\text { Extracted } \mathbf{0 . 5}\end{array}$ & Result \\
\hline Work Motivation (WM) & 0.976 & 0.893 & Reliable \\
\hline Leadership (JS) & 0.988 & 0.965 & Reliable \\
\hline Job Satisfaction (WM) & 0.986 & 0.947 & Reliable \\
\hline Job Performance (JB) & 0.970 & 0.866 & Reliable \\
\hline
\end{tabular}

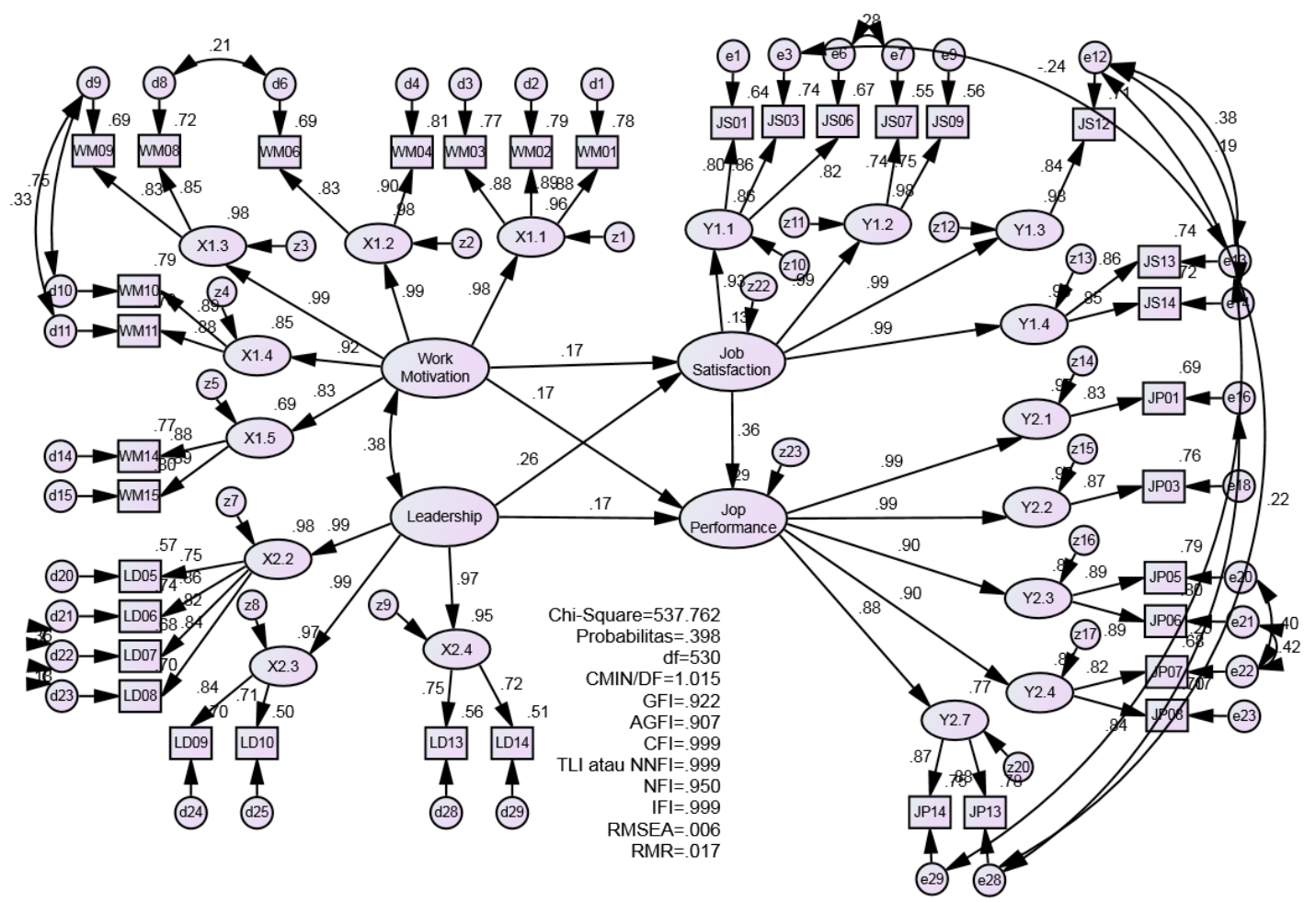

Figure 1. Full Model of Research

Table 4: Structural Parameter Estimates Direct Effect: Path Analysis Model $(N=354)$

\begin{tabular}{|l|c|c|c|c|}
\hline Hypothesis & Structural Path & $\begin{array}{c}\text { Standardized } \\
\text { Path } \\
\text { Coefficients }\end{array}$ & t-Value & Conclusion \\
\hline $\mathrm{H}_{1}$ & Work Motivation $\rightarrow$ Job Satisfaction & 0.171 & 2.874 & Significant \\
\hline $\mathrm{H}_{2}$ & Leadership $\rightarrow$ Job Satisfaction & 0.263 & 4.252 & Significant \\
\hline $\mathrm{H}_{3}$ & Work Motivation $\rightarrow$ Job Performance & 0.166 & 2.973 & Significant \\
\hline $\mathrm{H}_{4}$ & Leadership $\rightarrow$ Job Performance & 0.175 & 3.015 & Significant \\
\hline $\mathrm{H}_{5}$ & Job Satisfaction $\rightarrow$ Job Performance & 0.363 & 6.135 & Significant \\
\hline
\end{tabular}




\subsection{The Relationship between Leadership and Job Satisfaction}

Based on Table 4, the relationship between leadership and job satisfaction has value 4.252 (>1.96), so Hypothesis 2 is accepted. This leadership has a positive and significant effect on job satisfaction. Leadership is an essential factor in giving direction to employees. Which can foster employee motivation is leadership that can foster the confidence of employees in carrying out their respective duties. Therefore, the choice of leadership style that rightly applied to subordinates will have an impact on employee job satisfaction (ul Islam, Bangish, Muhammad, \& Jehan, 2016; Yukl, 2010). The results of this study are in line with the research of Munir et al. (2012), who revealed that transformational leadership and employee job satisfaction a positive, linear, and robust relationship $(\mathrm{r}=0.75)$. This study also supports the findings of Cakmak et al. (2015) showed that ethical leadership constructively has significant predictive ability regarding job satisfaction. Aderamo and Salau (2013) showed that transformational leadership had a positive impact on job satisfaction. Transactional leadership negatively influences job satisfaction. These findings also support the research result shown by Walumbwa et al. (2005) revealed that transformational leadership has a strong and positive effect on organizational commitment and job satisfaction in both cultures.

\subsection{The Relationship between Work Motivation and Job Performance}

Based on Table 4, the relationship between work motivation and job satisfaction has t value 2.973 (>1.96), so Hypothesis 3 is accepted. This work motivation has a positive and significant effect on job performance. Newstrom (2014) states that if better performance can increase employee benefits in a fair and balanced manner, then job satisfaction will increase; in other cases, employee satisfaction is an influential feedback self-image and motivation to improve performance. (Davis \& Newstrom, 1981) state that motivation is as a leader and employee attitude towards a situation in the organization. Those who are positive (pro) towards their work situation will show high work motivation and vice versa if they behave negatively (counter) to their work situation will show low work motivation. Employees who have high work motivation tend to give excellent performance.

The results of this study are in line with research by Haryono, Supardi, and Udin (2020), Grote and Grote (2011) which stated that increasing employee motivation would lead to an increase in the performance of individuals, groups, and organizations. This study also supports research by Arshadi (2010), who revealed that three psychological needs predicted work motivation and job performance. Hayati and Caniago (2012) showed the relationship between work motivation and job performance. Other research results that are in line are the research of (Imam et al., 2015) that reveals that there are three variables significantly affecting job performance; those variables are leadership style, corporate culture, and employee motivation. Azin and Reihane (2013) show the result that job motivation correlates with job performance.

\subsection{The Relationship between Leadership and Job Performance}

Based on Table 4, the relationship between leadership and job performance has t value 3.015 (>1.96), so Hypothesis 4 is accepted. This leadership has a positive and significant effect on job performance. According to Yukl (2010), effective leadership is leadership that can direct subordinates to carry out their duties well, motivate and move subordinates, and have better competencies so that employee performance will increase. Oluseyi and Hammed (2009) stated that leadership is essential at every level of organization; effective leadership moves individuals and groups to achieve organizational goals. Next, Akbar, Udin, and Djastuti (2018), Ivancevich and Konopaske (2012), Sulistiyani, Udin, and Rahardja (2018), Juan et al. (2012) stated that leaders are people who can provide work motives to subordinates in such a way that they want to work sincerely in order to achieve organizational goals effectively and efficiently.

The results of this study are in line with research by Kelidbari et al. (2016) that revealed that the role of ethical leadership in the performance of employees is indirectly significant. This research also supports the results of Semuel et al. (2017), who showed leadership influences on employee performance of hotels, either directly or indirectly, through innovation and differentiation as intervening variables. Research by Skeepers and Mbohwa (2015), who revealed that this research result supports leadership visibility and behavior in the construction industry.

\subsection{The Relationship between Job Satisfaction and Job Performance}

Based on Table 4, the relationship between job satisfaction and job performance has t value 6.135 (>1.96), so Hypothesis 5 is accepted. This job satisfaction has a positive and significant influence on job performance. According to Aamodt (2012), Le and Nguyen (2018), and Nguyen, Mai, Le, and Le (2018), the ultimate goal in Human Resource Management is the creation of job satisfaction for employees in a company. Job satisfaction has a positive effect on organizational performance. Dessler and Varrkey (2005) suggested that employees who get job satisfaction would have attendance records and obey better work rules. 
Employees who have job satisfaction w have better job performance than employees who do not get job satisfaction. From the description, that motivation and job satisfaction influence the performance

The results of this study are contrary to research by Djastuti, Rahardjo, Irviana, and Udin (2019), Kalkavan and Katrinli (2014), Maryati, Astuti, and Udin (2019) who gave the effect that between satisfaction and work performance. However, this study is in line with research by Farooqui and Nagendra (2014) showed the positive relationship between job satisfaction and job performance. Thus it can be proven that employee job satisfaction has a positive and significant effect on employee performance. The more satisfied employees in working, the better their performance will be.

Table 5 shows that the direct effect of leadership towards job satisfaction is more significant (0.263) than the direct effect of work motivation towards job satisfaction (0.171). The direct effect of leadership on job performance is more significant $(0.175)$ than the direct effect of work motivation on job performance. The effect of job satisfaction towards job performance is the most dominant or the biggest (0.363).

Table 6 shows that the indirect effect of work motivation towards job performance through job satisfaction is smaller (0.062) than the direct effect of work motivation towards job performance $(0.166)$. It means that job satisfaction does not have a mediating effect on this model. The policy implication for improving job performance at Bukit Asam Coal Mining Company can be done directly by increasing work motivation. The indirect effect of leadership towards job performance through job satisfaction is smaller (0.096) than the direct effect of work motivation on job performance $(0.175)$. It means that job satisfaction also does not have a mediating effect on this model. The policy implication for improving job performance at Bukit Asam Coal Mining Company can be done by directly increasing leadership capability.

Table 7 shows that the total effect of leadership towards job performance is more dominant or bigger $(0.270)$ than the total effect of work motivation towards job performance (228). The total effect of job satisfaction on job performance is the biggest (0.363). In general, the policy implication for improving job performance is recommended by increasing leadership (0.270) rather than work motivation (0.228) and then increasing job satisfaction (0.363).

\section{Conclusion}

Based on the results of the analysis and hypothesis testing, the results showed that leadership and work motivation proved to have a positive and significant effect on job satisfaction. Leadership has a more considerable influence $(0.263)$ than work motivation (0.171) on employee job satisfaction. All exogenous variables have a positive and significant effect on employee performance. Influential leadership is equal to 0.175 , powerful work motivation is 0.166 , and job satisfaction has the most dominant influence of 0.363 on employee performance. Leadership has a direct effect on employee performance of 0.175 , more significant than the indirect influence of leadership on employee performance through employee job satisfaction, which is only 0.096. Likewise, work motivation has a direct effect on employee performance of 0.166 more significant than the indirect effect of work motivation on employee performance through employee job satisfaction, which is only 0.062 .

Table 5: Standardized Direct Effects

\begin{tabular}{|l|c|c|c|c|}
\hline & Leadership & Wok Motivation & Job Satisfaction & Job Performance \\
\hline Job Satisfaction & .263 & .171 & .000 & .000 \\
\hline Job Performance & .175 & .166 & .363 & .000 \\
\hline
\end{tabular}

Table 6: Standardized Indirect Effects

\begin{tabular}{|l|c|c|c|c|}
\hline & Leadership & Wok Motivation & Job Satisfaction & Job Performance \\
\hline Wok Satisfaction & .000 & .000 & .000 & .000 \\
\hline Job Performance & .096 & .062 & .000 & .000 \\
\hline
\end{tabular}

Table 7: Standardized Total Effects

\begin{tabular}{|l|c|c|c|c|}
\hline & Leadership & Wok Motivation & Job Satisfaction & Job Performance \\
\hline Wok satisfaction & .263 & .171 & .000 & .000 \\
\hline Job Performance & .270 & .228 & .363 & .000 \\
\hline
\end{tabular}


Thus it can be concluded that job satisfaction does not mediate the influence of leadership and work motivation on employee performance. From the calculation of the total effect, job satisfaction has the most dominant total influence on employee performance (0.363) compared to leadership $(0.270)$ and work motivation $(0.228)$. The policy implication $t$ to improve the performance of acid hill employees is that management is more focused on improving employee satisfaction through increasing leadership capacity.

Suggestions for PT Bukit Asam, in improving employee performance so that priority is given to increasing job satisfaction, through leadership because the paths in the research model show the most significant total influence. However, acid hill pt must also pay attention to efforts to increase employee work motivation because this variable also influences psychotically and significantly on job satisfaction so that the impact will also improve employee performance even though not as big as leadership. The suggestion for the next researcher is to examine other mediation variables in this research model because, in this study, that job satisfaction does not play a role as a mediating variable.

\section{References}

Aamodt, M. (2012). Industrial/organizational psychology: An applied approach. Toronto: Nelson Education.

Aderamo, A., \& Salau, K. (2013). Parking patterns and problems in developing countries: A case from Ilorin, Nigeria. African Journal of Engineering Research, 1(2), 40-48. doi: http://www. netjournals.org/z_AJER_13_026.html

Akbar, A. B., Udin, S. W., \& Djastuti, I. (2018). Spiritual Leadership and Employee Performance: Mediating Role of Organizational Commitment in Indonesian Public University. Journal of Engineering and Applied Sciences, 13(12), 4344-4352. doi: docsdrive.com/pdfs/medwelljournals/jeasci/2018/4344-4352. pdf

Al-Khalifa, A. K., \& Peterson, S. (2004). On the relationship between initial motivation, and satisfaction and performance in joint ventures. European Journal of marketing, 30(2), 150-174. https://doi.org/10.1108/03090560410511168

Alnıaçık, Ü.,Alnıaçık, E., Akçin, K., \& Erat, S. (2012). Relationships Between Career Motivation, Affective Commitment and Job Satisfaction. Procedia - Social and Behavioral Sciences, 58, 355-362. https://doi.org/10.1016/j.sbspro.2012.09.1011

Anghelache, V. (2015). A Possible Explanatory Model for the Relationship between Teaching Motivation and Job Satisfaction. Procedia - Social and Behavioral Sciences, 180, 235-240. https://doi.org/10.1016/j.sbspro.2015.02.110

Araslı, H., Daşkın, M., \& Saydam, S. (2014). Polychronicity and Intrinsic Motivation as Dispositional Determinants on Hotel Frontline Employees' Job Satisfaction: Do Control Variables Make a Difference? Procedia - Social and Behavioral Sciences, 109, 1395-1405. https://doi.org/10.1016/j.sbspro.2013.12.643
Arshadi, N. (2010). Basic need satisfaction, work motivation, and job performance in an industrial company in Iran. Procedia Social and Behavioral Sciences, 5, 1267-1272. https://doi. org/10.1016/j.sbspro.2010.07.273

Awosusi, O. O., \& Fasanmi, S. S. (2014). Who's Next for the Axe? Procedural Justice and Job Insecurity among Bankers in Nigeria. Procedia - Social and Behavioral Sciences, 114, 403409. https://doi.org/10.1016/j.sbspro.2013.12.720

Azin, T., \& Reihane, D. (2013). Job Performance: Mediate Mechanism of Work Motivation. Procedia - Social and Behavioral Sciences, 1601-1605.

Cakmak, E., Öztekin, Ö., \& Karadağ, E. (2015). The effect of leadership on job satisfaction Leadership and organizational outcomes (pp. 29-56): Springer.

Cho, Y. (2020). Exploring Determinants of Performance Indicator and Customer Satisfaction of Accommodation Sharing. Journal of Asian Finance, Economics and Business, 7(3), 201-210. https://doi.org/10.13106/jafeb.2020.vol7.no3.201

Colquitt, J., Lepine, J. A., Wesson, M. J., \& Gellatly, I. R. (2011). Organizational behavior: Improving performance and commitment in the workplace (Vol. 375): McGraw-Hill Irwin New York, NY.

Davis, K., \& Newstrom, J. W. (1981). Human behavior at work: Organizational behavior: McGraw-Hill New York.

Dessler, G., \& Varrkey, B. (2005). Human Resource Management. India: Pearson Education.

Directorate of Mineral and Coal. (2010): Republic of Indonesia Ministry of Industry. Yogyakarta, Indonesia. Retrieved August 30, 2018, from https://www.esdm.go.id/en/profile/dutiesfunctions/directorate-general-of-mineral-and-coal.

Djastuti, I., Rahardjo, S., Irviana, L., \& Udin, U. (2019). Fun at work and employee performance: the roles of job satisfaction and organizational commitment in manufacturing companies. WSEAS Transactions on Business and Economics, 16, 153162.

Farooqui, M. S., \& Nagendra, A. (2014). The impact of person organization fit on job satisfaction and performance of the employees. Procedia economics and Finance, 11(2014), 122129.

Fo, D. (2015). Strategic management: concepts and cases; a competitive advantage approach. Boston: Pearson.

Gibson, J., Ivancevich, J., \& Konopaske, R. (2011). Organizations: Behavior, structure, processes. New York City: McGraw-Hill Higher Education.

Gomez-Mejia, L. R., Balkin, D. B., \& Cardy, R. L. (2012). Managing Human Resources. United State. India: Pearson Education.

Gordon, A., \& Yukl, G. (2004). The Future of Leadership Research: Challenges and Opportunities. German Journal of Human Resource Management, 18(3), 359-365. doi: $10.1177 / 239700220401800307$

Grote, R. C., \& Grote, D. (2011). How to be good at performance appraisals: Simple, effective, done right. New York: Harvard Business Review Press. 
Hair, J. F., Black, W., Babin, B., \& Anderson, R. (2013). Multivariate Data Analysis. Always learning. India: Pearson Education Limited.

Haryono, S., Supardi, S., \& Udin, U. (2020). The effect of training and job promotion on work motivation and its implications on job performance: Evidence from Indonesia. Management Science Letters, 10(9), 2107-2112. doi: 10.5267/j.msl.2020.1.019

Hayati, K., \& Caniago, I. (2012). Islamic Work Ethic: The Role of Intrinsic Motivation, Job Satisfaction, Organizational Commitment and Job Performance. Procedia - Social and Behavioral Sciences, 65, 1102-1106. https://doi.org/10.1016/j. sbspro.2014.05.148

Imam, S. L., Armanu, T., Umar, N., \& Djumahir. (2015). The Role of Cooperative Culture and Employee Motivation as a Mediating variable of Leadership Style related with the Employee Performance (Study in Perumperhutani). Procedia - Social and Behavioral Sciences, 211, 1142-1147. doi: 10.1016/j.sbspro.2015.11.152

Ivancevich, M. J., \& Konopaske, R. (2012). Human Resource Management. New York: McGraw-Hill Education.

Juan, S., Clare, M., Steve, B., \& Alan, P. (2012). Human Resource Development: Strategy and Tactics. Oxford: Elsevier Butterworth-Heinemann.

Kalkavan, S., \& Katrinli, A. (2014). The Effects of Managerial Coaching Behaviors on the Employees' Perception of Job Satisfaction, Organisational Commitment, and Job Performance: Case Study on Insurance Industry in Turkey. Procedia - Social and Behavioral Sciences, 150, 1137-1147. https://doi.org/10.1016/j.sbspro.2014.09.129

Kelidbari, H. R. R., Fadaei, M., \& Ebrahimi, P. (2016). The Role of Ethical Leadership on Employee Performance in Guilan University of Medical Sciences. Procedia - Social and Behavioral Sciences, 230, 463-470. https://doi.org/10.1016/j. sbspro.2016.09.058

Kinicki, A., \& Fugate, M. (2015). Organizational Behavior: A Practical, Problem-Solving Approach. New York: McGraw Hill.

Lo, V. M. L., Ngui, K. S., \& Ayob, N. B. (2011). The Influence of Leadership Styles on Employees' Job Satisfaction in Public Sector Organizations In Malaysia. International Journal of Business, Management, and Social Sciences, 2(1), 24-32.

Maryati, T., Astuti, R. J., \& Udin, U. (2019). The Effect of Spiritual Leadership and Organizational Culture on Employee Performance: The Mediating Role of Job Satisfaction. International Journal of Innovation, Creativity, and Change, 9(3), 130-143.

Mehta, R., Dubinsky, A. J., \& Anderson, R. E. (2003). Leadership Style, Motivation and Performance in International Marketing Channel. New Jersey, USA: School of Management. Institute of Technology.

Munir, R. I. S., Rahman, R. A., Malik, A. M. A., \& Ma'amor, H. (2012). Relationship between Transformational Leadership and Employees' Job Satisfaction among the Academic Staff. Procedia - Social and Behavioral Sciences, 65, 885-890. https:// doi.org/10.1016/j.sbspro.2012.11.215

Newstrom, J. (2014). Organizational Behavior: Human Behavior at Work. New York: Business \& Economics.

Oluseyi, S. A., \& Hammed, A. T. (2009). Influence of Work Motivation, Leadership Effectiveness, and Time Management on Employee's Performance in Some Selected Industries in Ibadan, Oyo State, Nigeria. European Journal of Economics, Finance, and Administrative Sciences, 16, 8-14.

Le, N. T. D., \& Nguyen, N. D. P. (2018). Organizational Justice, Job Satisfaction and Organizational Citizenship Behavior in Higher Education Institutions: A Research Proposition in Vietnam. Journal of Asian Finance, Economics and Business, 5(3), 113119. http://doi.org/10.13106/jafeb.2018.vol5.no3.113

Nguyen, N. D. P., Mai, N. K., Le, H. P., \& Le, N. T. D. (2018). The Effect of Two-Dimensional Factor on Municipal Civil Servants' Job Satisfaction and Public Policy Implications. Journal of Asian Finance, Economics and Business, 5(3), 133-142. http:// doi.org/10.13106/jafeb.2018.vol5.no3.133

Sekaran, U., \& Bougie, R. (2013). Research Methods for Business. New York: Willey.

Semuel, H., Siagian, H., \& Octavia, S. (2017). The Effect of Leadership and Innovation on Differentiation Strategy and Company Performance. Procedia - Social and Behavioral Sciences, 237, 1152-1159. https://doi.org/10.1016/j. sbspro.2017.02.171

Skeepers, N. C., \& Mbohwa, C. (2015). A Study on the Leadership Behaviour, Safety Leadership and Safety Performance in the Construction Industry in South Africa. Procedia Manufacturing, 4, 10-16. https://doi.org/10.1016/j.promfg.2015.11.008

Sulistiyani, E., Udin, \& Rahardja, E. (2018). Examining the effect of transformational leadership, extrinsic reward, and knowledge sharing on the creative performance of Indonesian SMEs. Quality - Access to Success, 19(167), 63-67.

ul Islam, Z., Bangish, S. B., Muhammad, H., \& Jehan, A. S. (2016). The impact of HR practices on job satisfaction: A case study of hotel industry in Pakistan. Journal of Asian Finance, Economics and Business, 3(1), 43-48. https://doi.org/10.13106/jafeb.2016. vol3.no1.43

Walumbwa, O. F., Bani, O., Peng, W., \& John, L. J. (2005). Transformational leadership, organizational commitment, and job satisfaction: A comparative study of Kenyan and U.S. financial firms. Human Resource Management Quarterly, $16(2), 235-256$.

Wikaningrum, T., Udin, \& Yuniawan, A. (2018). The relationships among leadership styles, communication skills, and employee satisfaction: A study on equal employment opportunity in leadership. Journal of Business and Retail Management Research, 13(1), 125-134.

Yukl, G. (2010). Leadership in Organizations, Seventh (7th) Edition. New York: Pearson Education. 